\title{
Antibacterial activity of taro (Colocasia esculenta L.) leaves extracts against Staphylococcus aureus and Vibrio parahaemolyticus and its effect on microbial population in sardine (Sardinella longiceps Val.)
}

\author{
${ }^{1}$ Padzil, K.N.M, ${ }^{2}$ Ayob, N.M, ${ }^{2}$ Alzabt, A.M. and ${ }^{1,2, * R u k a y a d i, ~ Y . ~}$ \\ ${ }^{1}$ Laboratory of Natural Medicine, Institute of Bioscience, Universiti Putra Malaysia, 43400, Serdang, \\ Selangor Darul Ehsan, Malaysia \\ ${ }^{2}$ Faculty of Food Science and Technology, Universiti Putra Malaysia, 43400, Serdang, Selangor \\ Darul Ehsan, Malaysia
}

\section{Article history:}

Received: 12 August 2020

Received in revised form: 17

September 2020

Accepted: 9 November 2020

Available Online: 27

February 2021

\section{Keywords:}

Colocasia esculenta L., Staphylococcus aureus, Vibrio parahaemolyticus, Microbial population, Sardine

\section{DOI:}

https://doi.org/10.26656/fr.2017.5(2).431

\begin{abstract}
Colocasia esculenta L. which is popularly known in Malaysia as "keladi" has extensive traditional uses for certain of the plant part such as the leaves, corm and stem. An earlier study has reported on the analysis of its pharmacological properties such as antiinflammatory and antibacterial activity. This study aimed to determine the antibacterial activity of C. esculenta L. leaves extracts against Staphylococcus aureus ATCC 29737 and Vibrio parahaemolyticus ATCC 17802 and its effect on the microbial population of sardine. The extract was tested for antibacterial activity against $S$. aureus and $V$. parahaemolyticus in term of disc diffusion assay (DDA), minimum inhibitory concentration (MIC), minimum bactericidal concentration (MBC) and killing time curve by using Clinical and Laboratory Standard Institute (CLSI) methods. DDA assay of the extract resulted in $8.40 \pm 0.10 \mathrm{~mm}$ and $8.20 \pm 0.16 \mathrm{~mm}$ of inhibition zone of the extract on $S$. aureus and $V$. parahaemolyticus, respectively. The extract can inhibit the growth of $S$. aureus and V. parahaemolyticus with MICs values of $1.25 \pm 0.00$ and $0.31 \pm 0.00 \mathrm{mg} / \mathrm{mL}$ and can kill the bacteria with MBCs values of $2.50 \pm 0.00$ and $0.63 \pm 0.00 \mathrm{mg} / \mathrm{mL}$, respectively. The killing time analyses showed that the $S$. aureus and $V$. parahaemolyticus can be killed completely for $4 \mathrm{hrs}$ at $2 \times \operatorname{MIC}(25.0 \mathrm{mg} / \mathrm{mL})$ and $2 \times \operatorname{MIC}(6.25 \mathrm{mg} / \mathrm{mL})$, respectively. Application of the extract on sardine samples shows significant reduction in total plate count (TPC), S. aureus and V. parahaemolyticus count after treated with $5.00 \%$ of the extract and stored at $4^{\circ} \mathrm{C}$ for 30 mins. Based on the findings, it indicates that $C$. esculenta L. can be listed as one of the alternatives natural sanitiser or preservative agent to reduce the bacterial loading of raw sardine prior to cooking.
\end{abstract}

\section{Introduction}

An illness caused by the consumption of food contaminated with pathogens has a wide economic and public health impact worldwide (Gandhi and Chikindas, 2007). Symptoms for foodborne illness include diarrhoea, abdominal pain, vomit, nausea and fever. Microorganisms such as Salmonella spp., Listeria monocytogenes, Escherichia coli O157:H7, Vibrio parahaemolyticus and Staphylococcus aureus are often reported as causative agents of foodborne diseases. The uses of food preservative or food sanitiser in the food industry exist to combat the growth of microorganism as well as to extend the shelf life of food. However, some of the chemicals preservative or sanitiser are harmful for human consumption and increase the safety issues.
Therefore, the medicinal plant has the potential as an alternative and safe antibacterial agent for human and environment to reduce the occurrence of food spoilage caused by foodborne pathogens and spoilage microorganisms. C. esculenta L. also called "keladi" in Malaysia is one of the potential natural plants that have been traditionally used worldwide as treatment of various ailments, flavouring in cooking and food products. Over 255 genetic diversities of C. esculenta $\mathrm{L}$. was studied by Kreike et al. (2004) and has been taken from various countries including Malaysia, Vietnam, Thailand, Indonesia, Philippines, Papua New Guinea and Vanuatu. According to Kubde et al. (2010), the young leaves of $C$. esculenta $\mathrm{L}$. are rich in vitamin $\mathrm{C}$ while the roots are rich in starch-containing thiamine, riboflavin, 
niacin, oxalic acid, calcium oxalate, sapotoxin and flavones, apigenin and luteolin. Anti-inflammatory, antibacterial and antifungal activities of $C$. esculenta L. was proven by several researchers which have contributed to its medicinal value and potential in the treatment of foodborne. Hence, the study is to determine the antibacterial activity of $C$. esculenta L. leaves extracts against Staphylococcus aureus ATCC 29737 and Vibrio parahaemolyticus ATCC 17802 in terms of disc diffusion, minimum inhibitory concentration (MIC), minimum bactericidal concentration (MBC) and the time -kill assay and to evaluate the effect of ethanolic $C$. esculenta L. leaves extract on the number of microorganism of raw sardine at different concentration, exposure time and storage temperature.

\section{Materials and methods}

\subsection{Plant extracts and sardine sample}

Colocasia esculenta L. extraction procedure was conducted according to the methods by Metwally et al. (2010). An organic solvent which is absolute ethanol ( $R$ $\&$ M Chemicals, 99.8\%) are used in the extraction of $C$. esculenta L. leaves. C. esculenta L. leaves $(2 \mathrm{~kg})$ were washed under running tap water, oven-dried at $40^{\circ} \mathrm{C}$ for $24 \mathrm{hrs}$ and was stored at ambient temperature away from the light. Briefly, $100 \mathrm{~g}$ of dried leaves of C. esculenta $\mathrm{L}$. was pulverized to a coarse powder. The samples were extracted with $400 \mathrm{~mL}$ of ethanol solvent for $48 \mathrm{hrs}$ at room temperature with occasional shaking. Whatman filter paper No. 2 (Whatman International Ltd., Middlesex, England) was used to filter the plant extracts. Rotary vacuum evaporator (BUCHI Rotavapor R-200, Switzerland) used to concentrate the extracts at $40^{\circ} \mathrm{C}$ for three to four hrs whereby yielded ethanolic crude extract of $C$. esculenta L. The extract was diluted into a final concentration of $1 \%(\mathrm{w} / \mathrm{v})$. All the crude extracts were subjected to freeze-drying for $48 \mathrm{hrs}$. Initially, $100 \mathrm{mg}$ of ethanolic crude extract was diluted in $1 \mathrm{~mL}$ of $100 \%$ dimethyl sulfoxide (DMSO) (R \& M Marketing, Essex, UK) to obtain $100 \mathrm{mg} / \mathrm{mL}$ and then further diluted in $1: 10(\mathrm{v} / \mathrm{v})$ distilled water to get $10 \mathrm{mg} / \mathrm{mL}(10000 \mu \mathrm{g} /$ $\mathrm{mL}$ ) stock solutions. C. esculenta L. leaves crude extract are collected and stored in the fridge $\left(-20^{\circ} \mathrm{C}\right)$ for use in further studies. While the raw sardine samples from groceries were bought at Seri Kembangan, Selangor. The samples were stored in the icebox at $4 \pm 2{ }^{\circ} \mathrm{C}$ during transportation. The sardine samples were processed immediately in less than 1 hour at Food Microbiology Laboratory, Faculty of Food Science and Technology, Universiti Putra Malaysia, Selangor, Malaysia upon arrival.

\subsection{Bacterial strains and inoculum preparation}

The antibacterial activity of $C$. esculenta L. leaves extract was evaluated against two bacterial species. They were Staphylococcus aureus and Vibrio parahaemolyticus, which were obtained from Bacteriology Food Safety Laboratory, Universiti Putra Malaysia, Selangor, Malaysia. The references control used throughout the study was S. aureus ATCC 29737 and $V$. parahaemolyticus ATCC 17802 from the American Type Culture Collection (Rockville, MD, USA). All the test strains were sub-cultured on Muller Hinton Agar (MHA) (Difco Becton Dickinson, Sparks, MD, USA), incubated at $37^{\circ} \mathrm{C}$ for $24 \mathrm{hrs}$ and stored at $4^{\circ}$ $\mathrm{C}$ in the refrigerator to maintain stock culture.

\subsection{Preparation of Mueller Hinton agar/ broth media}

Media preparation was conducted according to the manufacturer instructions provided on the media bottle (Oxoid Ltd., United Kingdom). Mueller-Hinton agar (MHA) was prepared by dissolving $10.5 \mathrm{~g}$ of MuellerHinton broth powder (Oxoid Ltd., United Kingdom) with $8.5 \mathrm{~g}$ of agar powder into $500 \mathrm{~mL}$ deionized water in 500 $\mathrm{mL}$ Schott's bottle. The solution sterilized using autoclave for 15 mins at $121^{\circ} \mathrm{C}$. Then, the sterilized agar was poured until it covers the surface of sterile petri plates. The petri plates were left at room temperature until solidified. The plates were then kept at $4{ }^{\circ} \mathrm{C}$ until further use. Mueller-Hinton broth (MHB) was prepared by dissolving $5.25 \mathrm{~g}$ of Mueller-Hinton broth powder (Oxoid Ltd., United Kingdom) with $250 \mathrm{~mL}$ deionized water in $250 \mathrm{~mL}$ Schott's bottle. The solution sterilized using autoclave for $15 \mathrm{mins}$ at $121^{\circ} \mathrm{C}$. Then, the sterilized solution was kept at $4^{\circ} \mathrm{C}$ until further use.

\subsection{Disc diffusion assay}

The initial determination of the antibacterial activity of the ethanolic extract of $C$. esculenta L. leaves was conducted by screening the susceptibility of the bacterial isolates to the plant extract and chlorhexidine ( $\mathrm{CHX}$ ) was used as a control by following the Kirby-Bauer diffusion method (Bauer et al., 1966). An overnight culture of each strain was spread on the Muller Hinton agar (Difco Becton Dickinson, Sparks, MD, USA) using a sterile cotton swab. Sterile paper disc $(6 \mathrm{~mm})$ was impregnated with $10 \mu \mathrm{L}$ of $5 \%$ plant extract. A $0.1 \%$ of chlorhexidine (CHX) was used as positive control and was prepared by dissolving $10 \mathrm{mg}$ of CHX (Sigma Aldrich, USA) sample in $1 \mathrm{~mL}$ of distilled water to make it $1 \%$ of CHX (stock solution). Then $100 \mu \mathrm{L}$ from stock solution was dissolved in $900 \mu \mathrm{L}$ of distilled water to make the final concentration of chlorhexidine into $0.1 \%$. The $0.1 \%$ of chlorhexidine was included as positive control while 
$10 \%$ of DMSO was used as the negative control. The discs were placed with equal distance between them on the agar plates. All the plates were then incubated at $37^{\circ}$ $\mathrm{C}$ for $24 \mathrm{hrs}$. The experiment was carried in three times in duplicates and the diameter of zones of inhibition formed was measured and their average determined using the method as reported by Clinical and Laboratory Standards Institute (CLSI, 2012). A clear inhibition zone around the impregnated disc was the indication of the presence of antibacterial.

\subsection{Determination of minimum inhibitory concentration (MIC)}

The Minimum Inhibitory Concentration (MIC) of $C$. esculenta L. leaves extract for each isolate was performed on MHB according to Clinical and Laboratory Standard Institute M7-A9 (CLSI, 2012) with a slight modification. This test was performed in 96-well microtiter plate using a two-fold standard broth microdilution method. A two-fold dilution of $C$. esculenta L. leaves extracts stock solution mixed with the bacterial isolates in MHB was filled in the 96-well microtiter. The first columns of the wells were filled with $200 \mu \mathrm{L}$ of $\mathrm{MHB}$ which served as negative control growth. The second columns, positive control growth columns were filled with $200 \mu \mathrm{L}$ of the bacterial suspension. The microdilution was performed at concentration ranged from $5 \mathrm{mg} / \mathrm{mL}$ in column twelve to $0.01 \mathrm{mg} / \mathrm{mL}$ in column three. The microtiter plate was then incubated at $37^{\circ} \mathrm{C}$ for $24 \mathrm{hrs}$. According to Talaro and Chess (2012), the MIC can be interpreted as the lowest concentration of the antibacterial agent that visually inhibits the growth of microorganisms after overnight incubation. The first well with no visible growth after the incubation period was taken as the MIC.

\subsection{Determination of minimum bactericidal concentration $(M B C)$}

The minimum bactericidal concentration (MBC) is the minimal concentration of antibacterial that kills the inoculums and can be determined from broth dilution MIC test by subculturing into MHA medium (approximately of $10 \mu \mathrm{L}$ ) without any antibacterial agents (French, 2006; Rukayadi et al., 2009). A volume of $10 \mu \mathrm{L}$ from all the wells from column one to twelve was pipetted onto the agar plates. The plate was then incubated at $37^{\circ} \mathrm{C}$ for $24 \mathrm{hrs}$. $\mathrm{MBC}$ is defined as the lowest concentration with no visible growth on MHA plates or the lowest concentration of antibacterial agent whereby the $S$. aureus and $V$. parahaemolyticus in the culture were completely killed.

\subsection{Time-kill assay}

The time-kill assay study of $C$. esculenta L. leaves extract was carried out to assess the killing rate of the extract within a given contact time. In this study, the assay was done according to the CLSI reference method, with slight modification. The extract of $C$. esculenta L. leaves with different concentration $(0 \times \mathrm{MIC}, 0.5 \times \mathrm{MIC}$, $1 \times \mathrm{MIC}, 2 \times \mathrm{MIC}, 4 \times \mathrm{MIC}$ ) were mixed with inoculum. All isolates were incubated at $37^{\circ} \mathrm{C}$ with $150 \mathrm{rpm}$ agitation at predetermined time points $(0,15$ and $30 \mathrm{mins}$ as well 1,2 and $4 \mathrm{hrs}$ ). Aliquots of $100 \mu \mathrm{L}$ were removed from each concentration at each of the time points and spread on the MHA medium. The plate was then incubated at $37^{\circ} \mathrm{C}$ for $24 \mathrm{hrs}$. After incubation, the agar plates were observed visually for the presence of growth. The number of colonies formed on the plate was counted and the number was recorded as $\log _{10}(\mathrm{CFU} / \mathrm{mL})$. Assays were carried out two times in duplicate. Time-kill curves were constructed by plotting the $\log _{10} \mathrm{CFU} / \mathrm{mL}$ versus time (Rukayadi et al., 2009).

\subsection{Effect of Colocasia esculenta L. leaves extract on the} number of microorganisms of raw sardine at different concentration, exposure time and storage temperature

The raw sardine sample was treated to the ethanolic extract of $C$. esculenta L. leaves at different concentration of $5.00 \%, 0.50 \%, 0.05 \%, 0.00 \%$ and sterile tap water. These treatments were exposed in $0 \mathrm{~min}, 15$ mins and 30 mins at room temperature $\left(22 \pm 2^{\circ} \mathrm{C}\right)$ and chiller $\left(4 \pm 2^{\circ} \mathrm{C}\right)$.

\subsubsection{Preparation of ethanolic Colocasia esculenta \\ L. leaves extract at different concentration}

Preparation of C. esculenta L. extract for raw sardine treatment was conducted by using the method reported by Yusoff et al. (2015) with some modification. In this treatment, the sterile de-ionized water (DIW) (B Braun Medical Industries, Penang, Malaysia) was used to prepare different concentration of $C$. esculenta L. extract $(5.00 \%, 0.50 \%$ and $0.05 \%)$ to be used later, in the application to raw sardine samples. A $5 \mathrm{~g}$ of C. esculenta L. leaves extract was diluted in $50.0 \mathrm{~mL}$ of DIW to make $10 \%$ concentration of $C$. esculenta $\mathrm{L}$. extract. The $5.0 \%$ concentration was prepared by pipetted $12.5 \mathrm{~mL}$ of the $10 \%$ extract concentration and diluted with $12.5 \mathrm{~mL}$ of DIW. A $22.5 \mathrm{~mL}$ DIW was added into $2.5 \mathrm{~mL}$ of $5 \%$ extract concentration to make the extract concentration of $0.50 \%$. For final concentration $0.05 \%$ preparation, 2.5 $\mathrm{mL}$ of $0.5 \%$ extract concentration was diluted to $22.5 \mathrm{~mL}$ of DIW. Each concentration solution was prepared in a total of $25 \mathrm{~mL}$. 
2.8.2 Media enumeration for total plate count (TPC), Staphylococcus aureus and Vibrio parahaemolyticus

Total plate count (TPC) is considered as a gold standard method permits the bacterial growth to form a colony (Davey, 2011). In preparation of media enumeration, for TPC, a $17.5 \mathrm{~g}$ of Plate Count Agar (PCA) (OXOID, Hampshire, United Kingdom) was added to $1 \mathrm{~L}$ of distilled water for, for $S$. aureus, $108 \mathrm{~g}$ Mannitol Salt Agar (MSA) (OXOID, Hampshire, United Kingdom) was suspended in $1 \mathrm{~L}$ of distilled water, meanwhile for $V$. parahaemolyticus of $88.1 \mathrm{~g}$ of Thiosulfate Citrate Bile Salts Sucrose Agar (TCBSA) (OXOID, Hampshire, United Kingdom) was suspended in $1 \mathrm{~L}$ of distilled water. PCA and MSA was sterilized by autoclaving at $121^{\circ} \mathrm{C}$ for 15 mins. TCBSA was slowly bringing to boiling, stirring, with constant agitation until complete dissolution. TCBSA was transferred immediately to a water bath at $50^{\circ} \mathrm{C}$. The sterilized solution was left to be cooled down before being poured into sterile Petri dish. An aliqout $(0.1 \mathrm{~mL})$ of each dilution was spread on TPC agar. The logarithm numbers of colony forming unit per grams $\left(\log _{10} \mathrm{CFU} / \mathrm{g}\right)$ of samples was calculated by observing and enumerating the total colonies (for TPC), yellowish colonies with yellow zones (for $S$. aureus) and colonies with blue to green centers (for $V$. parahaemolyticus) formed after incubation at $35^{\circ} \mathrm{C}$ for $48 \mathrm{hrs}$. After incubation, the macroscopic colonies grow on the plate were counted and calculated into CFU/g of the sample, by dividing the number of colonies with the amount of plated sample volume that has been multiplied with the dilution factor. The calculated amounts were then converted to $\log _{10}$ $\mathrm{CFU} / \mathrm{g}$ for the easiness of comparative purpose. All analysis was performed in two times in duplicate for data verification.

\subsubsection{Treatment of sardine sample with Colocasia esculenta L. leaves extract}

The raw sardine sample was cut and weighed for $5 \mathrm{~g}$. Each samples were treated with different concentrations of $C$. esculenta L. leaves extract $(0.00 \%, 0.05 \%, 0.50 \%$ and $5.00 \%$ ) and deionized water (DIW) in $4 \mathrm{~mL}$ volume at different exposure time of 0,15 and 30 mins. The treated samples were kept individually in sterile universal bottles as in Figure 3.6. All the samples were then stored at two different temperatures of $22 \pm 2^{\circ} \mathrm{C}$ and $4 \pm 2^{\circ} \mathrm{C}$. Next, the serial dilutions was done by pipetted 10 $\mu \mathrm{L}$ from each treatment and diluted into $990 \mu \mathrm{L}$ of phosphate buffer saline $(0.1 \%)$ to create $10-2$ and $10-4$ dilution. A $10 \mu \mathrm{L}$ from each dilution series were spread on the selective agar as previously mentioned. The agar plates were incubated as according to the requirement of respective media used. The logarithm numbers of colony forming unit per grams $\left(\log _{10} \mathrm{CFU} / \mathrm{g}\right)$ of samples were calculated by observing and enumerating the presumptive colonies formed after incubation. Referring to Yusoff et al. (2015), the experiments were done two times with duplicate $(\mathrm{n}=2 \times 2)$.

\subsection{Statistical data analysis}

The means value of microbial populations $\left(\log _{10}\right.$ $\mathrm{CFU} / \mathrm{g}$ ) from each treatment series were calculated for total plate count, $S$. aureus and $V$. parahaemolyticus count in a duplicate manner on each experiment. Minitab (B) Version 16 for Windows (Minitab Inc.) application software was used to analyze the data for variance (OneWay ANOVA), to find out the significant differences among the means for each treatment. The Tukey's test was used to determine the significant effect at $95 \%$ confidence level $(\mathrm{p}<0.05)$ between the factors; treatment group, exposure time and storage temperature. The results were expressed as mean \pm standard deviation (SD) of duplicate analyses.

\section{Results and discussion}

\subsection{Antibacterial activities}

According to the principle of DDA, a large inhibition zone or ring will form around the disc after incubation indicating great of antibacterial activity. The effect of the ethanolic extract of $C$. esculenta L. leaves and stem against $S$. aureus and $V$. parahaemolyticus were identified and the results the inhibition zone were summarized in Table 1.

Table 1. DDA of C. esculenta L. extracts against $S$. aureus and V. parahaemolyticus

\begin{tabular}{|c|c|c|}
\hline \multirow[b]{2}{*}{ Testing Organisms } & \multicolumn{2}{|c|}{ Inhibition Zone (mm) } \\
\hline & $\begin{array}{c}\text { S. aureus } \\
\text { ATCC } 297370 \\
\end{array}$ & $\begin{array}{c}\text { V. parahaemolyticus } \\
\text { ATCC } 17802\end{array}$ \\
\hline Control (Chlorhexidine) & $10.8 \pm 0.6^{\mathrm{a}}$ & $10.1 \pm 0.2^{\mathrm{a}}$ \\
\hline $\begin{array}{l}\text { C. esculenta L. stem } \\
\text { extract }\end{array}$ & $8.1 \pm 0.1^{\mathrm{b}}$ & $7.4 \pm 0.1^{\mathrm{bc}}$ \\
\hline $\begin{array}{l}\text { C. esculenta L. leaf } \\
\text { extract }\end{array}$ & $8.4 \pm 0.1^{\mathrm{b}}$ & $7.7 \pm 0.1^{\mathrm{b}}$ \\
\hline
\end{tabular}

Values are expressed as mean \pm standard deviation. Values with the different superscript within the row are significantly different at $\mathrm{P}<0.05$.

The result from Table 1 shows that the ethanolic extract of $C$. esculenta L. leaves was potent compared to stem extract with an inhibition zone of $8.4 \pm 0.1$ and $7.7 \pm 0.1$ against $S$. aureus and $V$. parahaemolyticus, respectively. The principle of the disc-diffusion method is the larger the inhibition zone meaning has a greater antibacterial activity. The result for $C$. esculenta $\mathrm{L}$. leaves extract was found to be statistically significant when compared with the standard control, chlorhexidine where the $\mathrm{P}$-value is 0.00 which is $(\mathrm{p}<0.05)$.

S. aureus is one of the most encountered pathogens 
in health concern and is known to have strong resistance against many conventional antibiotics. In a previous study by Dutta et al. (2017) reported that the antibacterial activity of ethanolic extract of $C$. esculenta against $S$. aureus showed the inhibition zone of $8.24 \pm 0.66 \mathrm{~mm}$. A research done by Ehiobu et al. (2018), they analyzed quantitatively for selected phytochemicals, such as tannins, flavonoids, alkaloids, saponins, steroids, phenols and cardiac glycosides and found that the flavonoids and tannins extracts have also been reported to possess antioxidants and antibacterial properties, at which its antifungal activities is the highest. This was supported by Wafa et al. (2016), reported that alkaloids present in most stem barks, leaves and roots of plants have long been recorded to possess potent antibacterial properties.

The antibacterial activity of $C$. esculenta L. leaves extract on $V$. parahaemolyticus has been reported in several studies. In one study by Wei et al. (2008), the ability of $C$. esculenta L. leaves extract to inhibit the growth of all tested Vibrio spp. and C. freundii was found. In this study, the largest inhibition zone with a diameter of $12 \mathrm{~mm}$ was recorded against Vibrio harveyi, and $9 \mathrm{~mm} V$. parahaemolyticus. Among all the five Vibrio spp. used ( $V$. cholera, $V$. alginolyticus, $V$. parahaemolyticus, $V$. harveyi and $V$. vulnificus). $V$. vulnificus showed the least inhibition zone diameter which is $8 \mathrm{~mm}$ when treated with the $C$. esculenta $\mathrm{L}$. leaves extract, while the stem and legume extract shows no inhibition zone in the DDA test.

It is proved that the medicinal plant like $C$. esculenta L. leaves possesses strong antibacterial properties, which very potential to be listed as one of the alternatives natural sanitiser or preservative agent to reduce the bacterial loading of raw sardine prior cooking. Othman et al. (2011) claimed that the DDA test is not so optimal for fully access the antibacterial activity since there was a restriction problem. This is because the data obtained from DDA is inadequate as the assay provides only qualitative data and acts as preliminary screening (Smith -Palmer et al., 1998). Therefore, through the determination of minimum inhibitory concentration (MIC) and minimum bactericidal concentration (MBC) values, the quantitative analyses of the $C$. esculenta $\mathrm{L}$. leave extract on the antibacterial activity were obtained.

\subsection{Minimum inhibitory concentration and Minimum} bactericidal concentration of Colocasia esculenta $L$. leaves extract against Staphylococcus aureus and Vibrio parahaemolyticus

The antibacterial activity of $C$. esculenta $\mathrm{L}$. leaves extract was further confirmed by the determination of MIC and MBC. As mentioned by Talaro and Chess
(2012), MIC is the lowest concentration of the antibacterial agent that visually inhibits the growth of microorganisms after overnight incubation. Meanwhile, $\mathrm{MBC}$ is standing for the lowest concentration of antibacterial agent that completely killed the growth of culture after endpoint (12-24 hrs).

Table 2 represents the comparative $\mathrm{MIC}$ and $\mathrm{MBC}$ assessment of $C$. esculenta L. leaves extract, positive and negative control against $S$. aureus and $V$. parahaemolyticus. The results in Table 2 revealed that ethanolic extract of $C$. esculenta L. leaves exhibit antibacterial activity against all the tested microorganisms. The extract was found to inhibit the growth of $S$. aureus and $V$. parahaemolyticus at MIC value of $12.50 \mathrm{mg} / \mathrm{mL}$ and $3.13 \mathrm{mg} / \mathrm{mL}$, respectively. The MBC values also have been obtained in this study with $25.00 \mathrm{mg} / \mathrm{mL}$ and $6.25 \mathrm{mg} / \mathrm{mL}$ for $S$. aureus and $V$. parahaemolyticus, respectively. According to Nduche et al. (2016), there were variations in the activity of MIC of ethanolic $C$. esculenta L. extract against $S$. aureus at a different concentration ranging from $50 \mathrm{mg} / \mathrm{mL}$ to 200 $\mathrm{mg} / \mathrm{mL}$. In addition, Ramli et al. (2017) reported that $L$. monocytogenes and $S$. aureus were found to be the most susceptible pathogen against $S$. polyanthum $\mathrm{L}$. extract with the MIC value of $0.63 \mathrm{mg} / \mathrm{mL}$.

Table 2. MIC and MBC of C. esculenta L. leaves extract against $S$. aureus and $V$. parahaemolyticus

\begin{tabular}{|c|c|c|c|c|}
\hline & \multicolumn{4}{|c|}{ Concentration $(\mathrm{mg} / \mathrm{mL})$} \\
\hline & \multicolumn{2}{|c|}{$\begin{array}{c}\text { S. aureus } \\
\text { ATCC } 29737\end{array}$} & \multicolumn{2}{|c|}{$\begin{array}{l}\text { V. parahaemolyticus } \\
\text { ATCC } 17802\end{array}$} \\
\hline & MIC & $\mathrm{MBC}$ & MIC & MBC \\
\hline $\begin{array}{l}\text { Positive Control } \\
\text { (Chlorhexidine) }\end{array}$ & 0.098 & 0.195 & 0.195 & 0.39 \\
\hline $\begin{array}{l}\text { Negative Control } \\
\text { (DMSO) }\end{array}$ & 0 & 0 & 0 & 0 \\
\hline $\begin{array}{l}\text { C. esculenta L. leaves } \\
\text { extract }\end{array}$ & 12.5 & 25 & 3.13 & 6.25 \\
\hline
\end{tabular}

In the previous study by Ramli et al. (2017) showed that the $V$. cholerae and $V$. parahaemolyticus had the same MIC and MBC values $(1.25 \mathrm{mg} / \mathrm{mL})$, meaning these bacteria can be inhibited and killed at the same concentration of $S$. polyanthum L. extract. This result showed that Gram-positive bacteria were easier to inhibit compared to Gram-negative ones. Gram-negative bacteria have a hydrophilic outer membrane rich in lipopolysaccharide molecules. Therefore, it serves as a penetration barrier towards macromolecules (Witkowska et al., 2013). Analysis of the phytochemical constituents for $C$. esculenta L. leaves extract was confirmed in the presence of tannins, flavonoids, alkaloids, saponins, steroids, phenols and cardiac glycosides. Ehiobu et al. (2018) reported that folic acid alkaloids, alkylresorcinols, glycosides, phenolics, and resins (Chandra et al., 2012) 
are considering the reports of previous research, they could probably be the bioactive ingredients responsible for the observed antibacterial activities (Saad et al., 2014; Agyare et al., 2016; Adeosun et al., 2016; Gwa et al., 2017; Anyanwu et al., 2017; Ehiobu et al., 2018).

\subsection{Time-kill assay}

Generally, to evaluate the effect of antibacterial activities over time, the time-kill curves that monitor bacterial growth and death over a wide range of antibacterial concentrations has been frequently used. Figures 1 and 2 are the representative of the time-kill curve graph for the bacteria $S$. aureus and $V$. parahaemolyticus, respectively. In the time-kill assay, the results were presented in terms of the changes in the $\log _{10} \mathrm{CFU} / \mathrm{mL}$ of viable colonies which indicated a significant bactericidal activity, exhibited by the extract. According to Olajuyigbe and Afolayan (2012), once the viable colony counts were equal to $3 \log _{10} \mathrm{CFU} / \mathrm{mL}$ or have a greater reduction, it was deliberated to have bactericidal activity.

The result for the time-kill curve of the $C$. esculenta L. leaves extract against $S$. aureus is plotted and presented as in Figure 1. At $2 \times \mathrm{MIC}(25.0 \mathrm{mg} / \mathrm{mL})$ and $4 \times \operatorname{MIC}(50.0 \mathrm{mg} / \mathrm{mL}), S$. aureus was completely killed, after $4 \mathrm{hrs}$ and $2 \mathrm{hrs}$ of incubation time, respectively. From the results at $4 \times$ MIC concentrations, the bacterial activity of $S$. aureus decreases $99.9 \%\left(\geq 3 \log _{10}\right)$ of the total $\mathrm{CFU} / \mathrm{mL}$ in the original inoculum after $2 \mathrm{hrs}$ incubation. The results showed that $C$. esculenta $\mathrm{L}$. leaves extract can kill the strain completely after $4 \mathrm{hrs}$ of incubation time at a concentration of $2 \times \mathrm{MIC}(25.0 \mathrm{mg} /$ $\mathrm{mL}$ ). While Ramli et al. (2017) had reported the bactericidal activity of $S$. polyanthum leaves to extract on $S$. aureus at $4 \times \operatorname{MIC}(2.5 \mathrm{mg} / \mathrm{mL})$ after $4 \mathrm{hrs}$ of incubation time.

The result for the time-kill curve of $C$. esculenta L. leaves extract against $V$. parahaemolyticus ATCC 17802 is plotted and presented in Figure 2. At $2 \times$ MIC $(6.25$

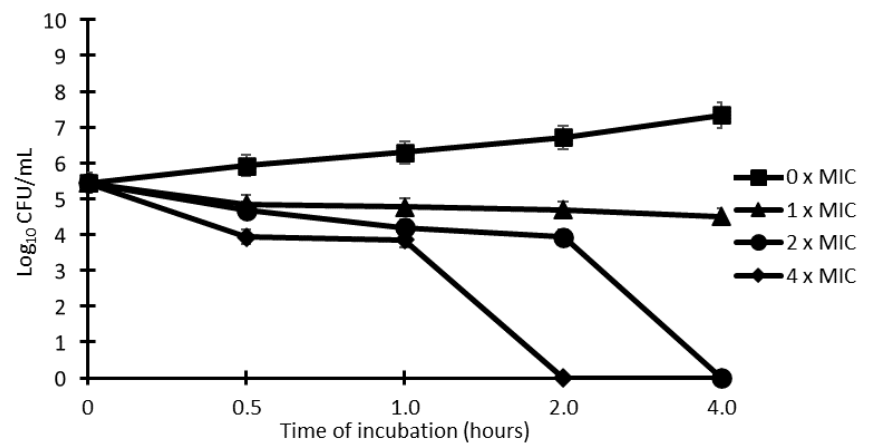

Figure 1. Time-kill curve plot of $S$. aureus ATCC 29737 for 0 $\times$ MIC, $0.5 \times \mathrm{MIC}, 1.0 \times \mathrm{MIC}, 2.0 \times \mathrm{MIC}$ and $4.0 \times \mathrm{MIC}$ of ethanolic $C$. esculenta L. leaves extracts at 0 to $4 \mathrm{hrs}$ incubation time $\mathrm{mg} / \mathrm{mL})$ and $4 \times$ MIC $(12.5 \mathrm{mg} / \mathrm{mL})$ of concentration, all $V$. parahaemolyticus were completely killed, after $4 \mathrm{hrs}$ and $2 \mathrm{hrs}$ of incubation time, respectively. From the results at $4 \times$ MIC concentrations, the bacterial activity of $V$. parahaemolyticus decreases $99.9 \%\left(\geq 3 \log _{10}\right)$ of the total $\mathrm{CFU} / \mathrm{mL}$ in the original inoculum after $2 \mathrm{hrs}$ incubation. The results show that $C$. esculenta $\mathrm{L}$. leaves extract can kill the strain completely after $2 \mathrm{hrs}$ of incubation time at a concentration of $4 \times$ MIC $(12.5 \mathrm{mg} /$ $\mathrm{mL}$ ). In contrast, Ramli et al. (2017) had reported the bactericidal activity of $S$. polyanthum leaves extract on $V$. parahaemolyticus at $4 \times \mathrm{MIC}(5.0 \mathrm{mg} / \mathrm{mL})$ for $4 \mathrm{hrs}$ of incubation time. In addition, Penduka and Okoh (2012) reported that $69 \%$ of $V$. parahaemolyticus was killed at $5 \mathrm{mg} / \mathrm{mL}$ after 2-hour incubation using Garcia kola seed methanol extract.

The results showed that $C$. esculenta L. leaves extract can kill $S$. aureus and $V$. parahaemolyticus at concentration $2 \times \operatorname{MIC}(25.0 \mathrm{mg} / \mathrm{mL})$ and $2 \times \operatorname{MIC}(6.25$ $\mathrm{mg} / \mathrm{mL}$ ) after $4 \mathrm{hrs}$ of incubation time, respectively. Therefore, this study revealed that the bactericidal effect of the plant extract was less effective to kill $S$. aureus compared to $V$. parahaemolyticus, as it required higher extract concentration. Furthermore, $S$. aureus was Grampositive bacteria where the membrane structure was easier to disrupt compared to Gram-negative bacteria. Increasing of plant extract's concentration will lead to diffusion into membrane cell thus causing membrane destruction (Thangiah et al., 2013).

\subsection{Effect of ethanolic Colocasia esculenta L. leaves extract on raw sardine samples}

The most important part of any food safety plan and quality control are the detection and enumeration of microorganisms in the food. These conventional test methods are simple, very practical, easily adaptable, and generally inexpensive. However, they can be difficult and depend on the growth of the microorganisms in different culture media (pre-enrichment, selective

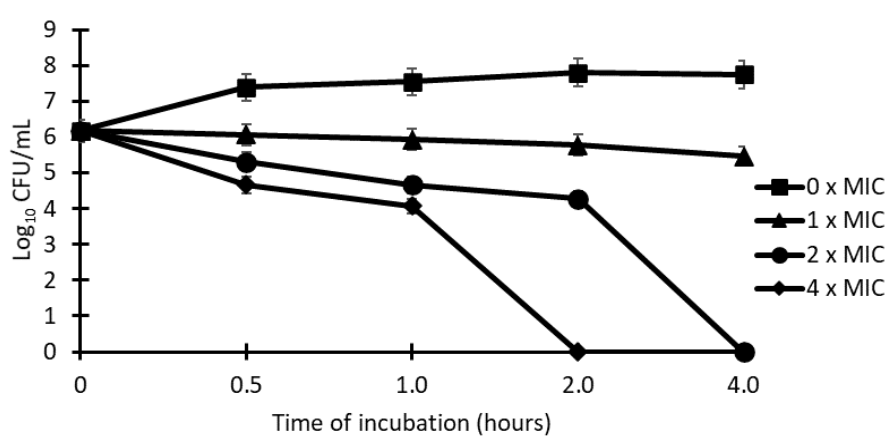

Figure 2. Time-kill curve plot of $V$. parahaemolyticus ATCC 17802 for $0 \times \mathrm{MIC}, 0.5 \times \mathrm{MIC}, 1.0 \times \mathrm{MIC}, 2.0 \times \mathrm{MIC}$ and 4.0 $\times$ MIC of ethanolic $C$. esculenta L. leaves extracts at 0 to $4 \mathrm{hrs}$ incubation time 
enrichment, selective plating, identification), which may require several days before results are known even not lacking sensitivity. Generally, cooling or refrigeration can only maintain the fish products freshness, but the microorganisms will not be eliminated, killed or stopped any enzymatic activity. This fact was supported by Ashie et al. (1996), which most biochemical spoilage process can be slow down at a lower temperature. Recently, antibacterial agents are frequently used in perishable products such as raw fish for the inhibition of growth of bacteria. In this study, $C$. esculenta L. leaves extract was used as an antibacterial agent to investigate the correlation between different concentrations of the extract with the storage of raw sardine samples.

\subsection{Total plate count (TPC) of sardine sample}

The result for TPC of sardine samples stored at room temperature and chiller were presented in Table 3. The findings show significant reduction of TPC $\left(\log _{10} \mathrm{CFU} /\right.$ g) for the treated samples from $0.05 \%, 0.50 \%$ to $5.00 \%$ concentrations of $C$. esculenta L. leaves extract accordingly, after 15 and 30 minute exposure time, while the TPC significantly increased when treated in $0.00 \%$ concentration. From Table 3, the TPC for samples treated at $0 \mathrm{~min}$ with all the treatment exceeded $10^{6}$ $\mathrm{CFU} / \mathrm{g}$ in both storage temperature (room temperature and chiller). When stored in the chiller, the microbial counts were significantly lower in each treatment and every exposure time, compared when stored at room temperature.

At high concentration, the extract has higher chances to express its antibacterial activity towards the bacterial loading on the sardine samples. Thus, fewer bacteria were survived at higher extract concentration $(5.00 \%)$ compared to a lower concentration $(0.05 \%)$. According to Unklesbay et al. (1992), due to the enzymatic and microbial spoilage caused by improper onsite storage, around 4-5 million tons of trawled and shrimp fish are lost every year. Thus, in preventing the spoilage of fish product, one of the most important factors is by controlling the storage temperature (Jay, 2000). Briefly, spoilage can be prevented by storing foods at or below $4^{\circ} \mathrm{C}$, using them immediately or storing them for longer periods at $-18^{\circ} \mathrm{C}$ or below. Chilling was recognized as one of the cold preservation that preserves the nutritional and sensory value of the food, but the temperature does not eliminate the harmful microorganism (Hiramatsu et al., 2005). According to Speck and Ray (1977), the lower temperature is able to control the microbiological activity during frozen by limiting the microbial growth and water activity (Aw). In this study, with the addition of antibacterial activity of $C$. esculenta L. leaves extract at $5.00 \%$ concentration, the bacterial count were decreasing significantly upon storage at $4^{\circ} \mathrm{C}$, compared with $0.05 \%$ extract concentration.

\subsection{Staphylococcus aureus count of sardine sample}

S. aureus is commonly found in the environment (soil, water and air) and is also found in the nose and on the skin of humans. According to Argudin et al. (2010), the main sources of food contaminations are from the food handlers which carrying enterotoxin-producing $S$. aureus in their noses or on their hands via direct contact or through respiratory secretions. Even though $S$. aureus is a poor competitor, but it is able to grow under osmotic and $\mathrm{pH}$ stress, meaning that it is capable of thriving in a wide variety of foods. The result for $S$. aureus count of raw sardine samples treated with different concentration of $C$. esculenta L. leaves extract, stored at room temperature and chiller were presented in Table 4. From the result, the sample treated with extract concentration of $0.05 \%, 0.50 \%$ and $5.00 \%$, showed a significant reduction of $S$. aureus $\left(\log _{10} \mathrm{CFU} / \mathrm{mL}\right)$ after $30 \mathrm{mins}$ exposure in the chiller.

From Table 4, upon chilling at $30 \mathrm{~min}$ exposure time, no $S$. aureus was able to survive when treated with $0.50 \%$ and $5.00 \%$ concentration of $C$. esculenta $\mathrm{L}$. extract. In this study, C. esculenta L. leaves extract express their antibacterial activity on the treated samples at an exposure time of $15 \mathrm{~min}$, where $0.50 \%$ and $5.00 \%$

Table 3. Total plate count $\left(\log _{10} \mathrm{CFU} / \mathrm{g}\right)$ of sardine sample treated with $C$. esculenta $\mathrm{L}$. leaves extract stored at room temperature and chiller for 0,15 and 30 minutes exposure time

\begin{tabular}{ccccccc}
\hline \multirow{2}{*}{$\begin{array}{c}\text { Temperature } \\
\text { Storage }\end{array}$} & Exposure & \multicolumn{5}{c}{ Extract Concentration (\%) } \\
\cline { 3 - 7 } & Time & Tap Water & 0 & 0.05 & 0.5 & 5 \\
\hline \multirow{2}{*}{$\begin{array}{c}\text { Room } \\
\text { Temperature }\end{array}$} & $0 \mathrm{~min}$ & $6.56 \pm 0.04^{\mathrm{Aa}}$ & $6.46 \pm 0.05^{\mathrm{aA}}$ & $6.50 \pm 0.11^{\mathrm{aA}}$ & $6.26 \pm 0.008^{\mathrm{aA}}$ & $6.37 \pm 0.07^{\mathrm{aA}}$ \\
& $15 \mathrm{~min}$ & $6.37 \pm 0.10^{\mathrm{abAB}}$ & $6.59 \pm 0.19^{\mathrm{aA}}$ & $6.42 \pm 0.08^{\mathrm{abA}}$ & $6.12 \pm 0.11^{\mathrm{bcA}}$ & $5.92 \pm 0.16^{\mathrm{cB}}$ \\
& $30 \mathrm{~min}$ & $6.34 \pm 0.01^{\mathrm{Ab}}$ & $6.64 \pm 0.05^{\mathrm{aA}}$ & $6.37 \pm 0.06^{\mathrm{aA}}$ & $5.91 \pm 0.17^{\mathrm{bA}}$ & $5.79 \pm 0.02^{\mathrm{bB}}$ \\
\hline \multirow{2}{*}{ Chiller } & $0 \mathrm{~min}$ & $6.56 \pm 0.04^{\mathrm{Aa}}$ & $6.46 \pm 0.05^{\mathrm{aA}}$ & $6.50 \pm 0.11^{\mathrm{aA}}$ & $6.26 \pm 0.008^{\mathrm{aA}}$ & $6.37 \pm 0.07^{\mathrm{aA}}$ \\
& $15 \mathrm{~min}$ & $6.30 \pm 0.09^{\mathrm{Aa}}$ & $6.53 \pm 0.07^{\mathrm{aA}}$ & $6.37 \pm 0.05^{\mathrm{aA}}$ & $5.92 \pm 0.11^{\mathrm{bAB}}$ & $5.72 \pm 0.02^{\mathrm{bB}}$ \\
& $30 \mathrm{~min}$ & $6.27 \pm 0.06^{\mathrm{Ba}}$ & $6.60 \pm 0.05^{\mathrm{aA}}$ & $6.12 \pm 0.10^{\mathrm{bA}}$ & $5.77 \pm 0.02^{\mathrm{cB}}$ & $5.44 \pm 0.05^{\mathrm{dC}}$ \\
\hline
\end{tabular}

Values are expressed as mean \pm standard deviation. Values with different lowercase superscript within the row are significantly different at $\mathrm{P}<0.05$ while value with different uppercase superscript within the column are significantly different at $\mathrm{P}<0.05$. 
Table 4. S. aureus count $\left(\log _{10} \mathrm{CFU} / \mathrm{g}\right)$ of sardine sample treated with $C$. esculenta $\mathrm{L}$. leaves extract stored at room temperature and chiller for 0,15 and 30 minute exposure time

\begin{tabular}{ccccccc}
\hline \multirow{2}{*}{$\begin{array}{c}\text { Temperature } \\
\text { Storage }\end{array}$} & Exposure & \multicolumn{5}{c}{ Extract Concentration (\%) } \\
\cline { 3 - 6 } & Time & Tap Water & 0 & 0.05 & 0.5 & 5 \\
\hline \multirow{2}{*}{$\begin{array}{c}\text { Room } \\
\text { Temperature }\end{array}$} & $0 \mathrm{~min}$ & $6.10 \pm 0.12^{\mathrm{Aa}}$ & $6.12 \pm 0.09^{\mathrm{aA}}$ & $6.02 \pm 0.00^{\mathrm{aA}}$ & $6.10 \pm 0.12^{\mathrm{aA}}$ & $6.12 \pm 0.11^{\mathrm{aA}}$ \\
& $15 \mathrm{~min}$ & $5.90 \pm 0.21^{\mathrm{Aa}}$ & $6.14 \pm 0.09^{\mathrm{aA}}$ & $5.89 \pm 0.20^{\mathrm{aA}}$ & $5.83 \pm 0.07^{\mathrm{aB}}$ & $5.87 \pm 0.19^{\mathrm{aA}}$ \\
& $30 \mathrm{~min}$ & $5.77 \pm 0.01^{\mathrm{Aa}}$ & $6.26 \pm 0.07^{\mathrm{aA}}$ & $5.89 \pm 0.16^{\mathrm{aA}}$ & $5.78 \pm 0.03^{\mathrm{aB}}$ & $5.40 \pm 0.56^{\mathrm{aA}}$ \\
\hline \multirow{2}{*}{ Chiller } & $0 \mathrm{~min}$ & $6.10 \pm 0.12^{\mathrm{Aa}}$ & $6.12 \pm 0.09^{\mathrm{aA}}$ & $6.02 \pm 0.00^{\mathrm{aA}}$ & $6.10 \pm 0.12^{\mathrm{aA}}$ & $6.12 \pm 0.11^{\mathrm{aA}}$ \\
& $15 \mathrm{~min}$ & $5.86 \pm 0.20^{\mathrm{aA}}$ & $6.14 \pm 0.11^{\mathrm{Aa}}$ & $5.89 \pm 0.19^{\mathrm{aA}}$ & $5.74 \pm 0.01^{\mathrm{aB}}$ & $5.82 \pm 0.05^{\mathrm{aB}}$ \\
& $30 \mathrm{~min}$ & $5.74 \pm 0.02^{\mathrm{bA}}$ & $6.21 \pm 0.00^{\mathrm{Aa}}$ & $5.86 \pm 0.19^{\mathrm{abA}}$ & $\mathrm{ND}^{\mathrm{cC}}$ & $\mathrm{ND}^{\mathrm{cC}}$ \\
\hline
\end{tabular}

Values are expressed as mean \pm standard deviation. Values with different lowercase superscript within the row are significantly different at $\mathrm{P}<0.05$ while value with different uppercase superscript within the column are significantly different at $\mathrm{P}<0.05$. ND, not detected.

extract concentration showed a reduction in the microbiological count, less than $106 \mathrm{CFU} / \mathrm{g}$ which were $5.74 \pm 0.01 \mathrm{CFU} / \mathrm{g}$ and $5.82 \pm 0.05 \mathrm{CFU} / \mathrm{g}$, respectively when stored in chiller. According to Hiramatsu et al. (2005), the chilling temperature does not eliminate the harmful microorganism, because as soon as the temperature becomes favourable, the spoilage microorganism is able to survive and resumed their activity. According to Casarin et al. (2009), the temperature is able to inactivate part of the bacterial population, and the magnitude of its effect will vary according to the type of food. In this study, the antibacterial effect of $C$. esculenta L. leaves extract was enhanced with the cold storage temperature $\left(4^{\circ} \mathrm{C}\right)$.

\subsection{Vibrio parahaemolyticus count of sardine sample}

In the study by Liu et al. (2009) summarized that the number of reported $V$. parahaemolyticus infections in Asia has increased significantly by year. This was supported by Harth et al. (2009) and Chang et al. (2011) which reported the most common Vibrio species associated with illnesses were $V$. parahaemolyticus and $V$. vulnificus that resulted from consumption of raw or partially cooked seafood. Table 5 shows the details for $V$. parahaemolyticus count for the treated samples with different concentration of $C$. esculenta L. leaves extract, stored at room temperature and chiller. Samples treated with tap water, $0.05 \%, 0.50 \%$ to $5.00 \%$ of extract concentration showed a significant reduction of $V$. parahaemolyticus $\left(\log _{10} \mathrm{CFU} / \mathrm{mL}\right)$ after 30 -minute exposure, stored in the chiller.

Samples that stored both at room temperature and chiller, the $V$. parahaemolyticus count showed reduction accordingly with increasing of the extract concentration $(0.05 \%, 0.50 \%$ and $5.00 \%)$. The most significant decrease in bacterial count occurred in the sample treated with $0.50 \%$ and $5.0 \%$ of extract concentration that can be seen when stored in the chiller, which able to kill $V$. parahaemolyticus as $V$. parahaemolyticus colonies did not grow over TCBS agar with a decrease of $5.0 \log _{10}$ $\mathrm{CFU} / \mathrm{mL}$ for both concentrations. In this study, application of the extract on the raw sardine samples significantly reduce the $V$. parahaemolyticus count through the antibacterial activity from the $C$. esculenta L. leaves extract that enhance by low storage temperature.

\section{Conclusion}

C. esculenta L. leaves extract scientifically reported with numerous beneficial phytochemicals that proved to have high antibacterial activity against $S$. aureus and $V$.

Table 5. V. parahaemolyticus count $\left(\log _{10} \mathrm{CFU} / \mathrm{g}\right)$ of sardine sample treated with $C$. esculenta $\mathrm{L}$. leaves extract stored at room temperature and chiller for 0,15 and 30 minute exposure time

\begin{tabular}{ccccccc}
\hline \multirow{2}{*}{$\begin{array}{c}\text { Temperature } \\
\text { Storage }\end{array}$} & Exposure & \multicolumn{5}{c}{ Extract Concentration (\%) } \\
\cline { 3 - 6 } & Time & Tap Water & 0 & 0.05 & 0.5 & 5 \\
\hline \multirow{2}{*}{$\begin{array}{c}\text { Room } \\
\text { Temperature }\end{array}$} & $0 \mathrm{~min}$ & $5.36 \pm 0.53^{\mathrm{aA}}$ & $5.30 \pm 0.60^{\mathrm{Aa}}$ & $5.27 \pm 0.65^{\mathrm{aA}}$ & $5.30 \pm 0.60^{\mathrm{aA}}$ & $5.28 \pm 0.61^{\mathrm{aA}}$ \\
& $15 \mathrm{~min}$ & $4.81 \pm 0.16^{\mathrm{bA}}$ & $5.73 \pm 0.01^{\mathrm{Aa}}$ & $4.86 \pm 0.02^{\mathrm{bA}}$ & $4.87 \pm 0.08^{\mathrm{bA}}$ & $4.74 \pm 0.27^{\mathrm{bA}}$ \\
& $30 \mathrm{~min}$ & $4.62 \pm 0.11^{\mathrm{abA}}$ & $5.74 \pm 0.00^{\mathrm{Aa}}$ & $4.62 \pm 0.11^{\mathrm{abA}}$ & $4.30 \pm 0.42^{\mathrm{bA}}$ & $4.04 \pm 0.50^{\mathrm{bA}}$ \\
\hline \multirow{2}{*}{ Chiller } & $0 \mathrm{~min}$ & $5.36 \pm 0.53^{\mathrm{aA}}$ & $5.30 \pm 0.60^{\mathrm{Aa}}$ & $5.27 \pm 0.65^{\mathrm{aA}}$ & $5.30 \pm 0.60^{\mathrm{aA}}$ & $5.28 \pm 0.61^{\mathrm{aA}}$ \\
& $15 \mathrm{~min}$ & $4.50 \pm 0.14^{\mathrm{bA}}$ & $5.72 \pm 0.00^{\mathrm{Aa}}$ & $4.57 \pm 0.04^{\mathrm{bA}}$ & $4.20 \pm 0.28^{\mathrm{bA}}$ & $4.09 \pm 0.12^{\mathrm{bA}}$ \\
& $30 \mathrm{~min}$ & $4.09 \pm 0.13^{\mathrm{bA}}$ & $5.73 \pm 0.01^{\mathrm{Aa}}$ & $3.85 \pm 0.21^{\mathrm{bA}}$ & $\mathrm{ND}^{\mathrm{cB}}$ & $\mathrm{ND}^{\mathrm{cB}}$ \\
\hline
\end{tabular}

Values are expressed as mean \pm standard deviation. Values with different lowercase superscript within the row are significantly different at $\mathrm{P}<0.05$ while value with different uppercase superscript within the column are significantly different at $\mathrm{P}<0.05$. ND, not detected. 
parahaemolyticus. Sardine samples treated with the extract stored at room temperature and chiller resulted in the continuous reduction of the bacterial count for both $S$. aureus and $V$. parahaemolyticus and showed bacterial count less than $106 \mathrm{CFU} / \mathrm{g}$; which is the safe microbial limits for fish and fish product. Among all the treatment, the optimum condition for sample storage can be achieved by using $5.00 \%$ extract concentration stored at $4^{\circ} \mathrm{C}$ for 30 mins. From the findings, it showed that $C$. esculenta L. leaves extract exhibits the potential natural antibacterial candidate as a food natural sanitiser or preservative agent to reduce the bacterial loading of raw sardine prior to cooking. Therefore, the reduction of microbial loading is very important in ensuring the food safeness as well as reducing the occurrence of foodborne poisoning associated with perishable product such as fish. The antibacterial mechanisms of the compound in the $C$. esculenta L. leaves extract can be further studied by referring to the results obtained in this study so that the benefits of the plants can be exploited.

\section{Conflict of interest}

The authors declare no conflict of interest.

\section{References}

Adeosun, O.M. (2016). Antibacterial activities and phytochemical properties of extracts of Dioscorea bulbifera Linn (Air Potato) tubers and peels against some pathogenic bacteria. Journal Phytopharmacology, 5(1), 20-26.

Agyare, C. (2016). Antimicrobial and anti-inflammatory properties of Anchomanes difformis (B1.) Engl. and Colocasia esculenta (L.) Schott. Biochemical Pharmacology, 5, 201. https://doi.org/10.4172/21670501.1000201

Anyanwu, M.U. and Okoye, R.C. (2017). Antimicrobial activity of Nigerian medicinal plants. Journal of Intercultural Ethnopharmacology, 6(2), 240-259. https://doi.org/10.5455/jice.20170106073231

Argudin, M.A., Mendoza, M.C. and Rodicio, M.R. (2010). Food poisoning and Staphylococcus aureus enterotoxins. Toxins, 2(7), 1751-1773. https:// doi.org/10.3390/toxins2071751

Ashie, I.N.A., Smith, J.P. and Simpson, B.K. (1996). Spoilage and shelf-life extension of fresh fish and shellfish. Critical Reviews in Food Science and Nutrition, 36(1-2), 87-121. https:// doi.org/10.1080/10408399609527720

Bauer, A.W., Kirby, W.M.M., Sherris, J.C.T. and Turck, M. (1966). Antibiotic susceptibility testing by a standardized single disk method. American Journal of Clinical Pathology, 45(4), 493-496. https:// doi.org/10.1093/ajcp/45.4_ts.493
Casarin, L.S., Tondo, E.C., Klein, M.P. and Brandelli, A. (2009). Survival of Escherichia coli, Staphylococcus aureus and Salmonella Enteritidis in frozen chicken hamburger. Journal of Muscle Foods, 20(4), 478488.

4573.2009.00162.x

https://doi.org/10.1111/j.1745-

Chandra, S., Saklani, S. and Singh, J. 2012. Phytochemical screening of Garhwal Himalaya wild edible tuber Colocasia Esculenta. International Research Journal of Pharmacy, 3(3), 181-196.

Chang, H.C., Chen, M.L., Su, Y.C., Pai, J.Y. and Chiu, T.H. (2011). Molecular characterizations of pathogenic Vibrio parahaemolyticus isolated from Southern Taiwan oyster-growing environment. Food Control Journal, 22(2), 245-251. https:// doi.org/10.1016/j.foodcont.2010.07.004

Clinical and Laboratory Standards Institute, (2012). Approved guidelines M100. Performance standard for antimicrobial susceptibility testing, 27th ed. Wayne, Philadelphia, USA: CLSI.

Davey, H.M. (2011). Life, death, and in-between: meanings and methods in microbiology. Applied and Environmental Microbiology, 77, 5571-5576. https:// doi.org/10.1128/AEM.00744-11

Dutta, S. and Aich, B. (2017). Study of antibacterial and antifungal activity of the leaves of $C$. esculenta $\mathrm{L}$. International Journal of Pharmaceutical Science and Research, 8(3), 1184-1187.

Ehiobu, J.M. and Ogu, G.I. 2018. Phytochemical content and in vitro antimycelial efficacy of Colocasia esculenta (L), Manihot esculenta (Crantz) and Dioscorea rotundata (Poir) leaf extracts on Aspergillus niger and Botryodiplodia theobromae. Journal of Horticulture and Plant Research, 1, 9-18. https://doi.org/10.18052/www.scipress.com/ JHPR.1.9

French, G.L. (2006). Bactericidal agents in the treatment of MRSA infections - the potential role of daptomycin. Journal of Antimicrobial Chemotherapy, 58(6), 1107-1117. https:// doi.org/10.1093/jac/dk1393

Gandhi, M. and Chikindas, M.L. (2007). Listeria: A foodborne pathogen that knows how to survive. International Journal of Food Microbiology, 113(1), $1-15$. https://doi.org/10.1016/ j.ijfoodmicro.2006.07.008

Gwa, V.I., Ekefan, E. and Nwankiti. (2017). Antifungal potency of some plant extracts in the control of white yam (Dioscorea rotundata Poir) tuber rots. Advance Biotechnology and Microbiology, 7(1), 555703. https://doi.org/10.19080/AIBM.2017.07.555703

Harth, E., Matsuda, L., Hernandez, C., Rioseco, M.L., Romero, J., Gonzalez-Escalona, N., MartinezUrtaza, J. and Espejo, R.T. (2009). Epidemiology of 
Vibrio parahaemolyticus outbreaks, southern Chile. Emerging Infectious Diseases Journal, 15, 163-168. https://doi.org/10.3201/eid1502.071269

Hiramatsu, R., Matsumoto, M., Sakae, K. and Miyazaki, Y. (2005). Ability of Shiga toxin-producing Escherichia coli and Salmonella spp. to survive in a desiccation model system and in dry foods. Applied and Environmental Microbiology, 71, 6657-6663. https://doi.org/10.1128/AEM.71.11.6657-6663.2005

Jay, J.M. (2000). Modern Food Microbiology, 6th ed., p. 283-295. USA: Aspen Publishers Inc. https:// doi.org/10.1007/978-1-4615-4427-2

Kreike, C.M., Van Eck, H.J. and Lebot, V. (2004). Genetic diversity of taro, Colocasia esculenta (L.) Schott, in Southeast Asia and the Pacific. Theoretical and Applied Genetics, 109, 761-768. https:// doi.org/10.1007/s00122-004-1691-z

Kubde, M.S., Khadabadi, S.S., Saboo, S.S., Ghorpade, D.S. and Modi, A.J. (2010). In vitro antimicrobial activity of the crude extracts of Colocasia esculenta leaves (araceae). International Journal of Pharmaceutical Sciences and Research, 1(8), 88-91.

Liu, F., Guan, W., Alam, M.J., Shen, Z., Zhang, S., Li, L., Shinoda, S. and Shi, L. (2009). Pulsed-field gel electrophoresis typing of multidrug-resistant Vibrio parahaemolyticus isolated from various sources of seafood. Journal of Health Science, 55(5), 783-789. https://doi.org/10.1248/jhs.55.783

Metwally, A.M., Omar, A.A., Harraz, F.M. and Sohafy, S.M. (2010). Phytochemical investigation and antimicrobial activity of Psidium guajava Linn. leaves. Pharmacognosy Magazine, 6(23), 212-218. https://doi.org/10.4103/0973-1296.66939

Olajuyigbe, O.O. and Afolayan, A.J. (2012). In vitro pharmacological activity of the crude acetone extract of Erythrina caffra Thunb: antibacterial and antifungal assessment. Journal of Medicinal Plants Research, 6(9), 1713-1720. https://doi.org/10.5897/ JMPR11.1517

Othman, M., Loh, H.S., Wiart, C., Khoo, T.J., Lim, K.H. and Ting, K.N. (2011). Optimal methods for evaluating antimicrobial activities from plant extracts. Journal of Microbiological Methods, 84(2), 161-166. https://doi.org/10.1016/ j.mimet.2010.11.008

Penduka, D. and Okoh, A.I. (2012). In vitro antilisterial properties of crude methanol extracts of Garcinia kola (Heckel) seeds. The Scientific World Journal, 2012, 694828. https://doi.org/10.1100/2012/694828

Ramli, S., Radu, S., Shaari, K. and Rukayadi, Y. (2017). Antibacterial Activity of Ethanolic Extract of Syzygium polyanthum L. (Salam) Leaves against Foodborne Pathogens and Application as Food Sanitiser. BioMed Research International, 2017,
9024246. https://doi.org/10.1155/2017/9024246. https://doi.org/10.1155/2017/9024246

Rukayadi, Y., Lee, K., Han, S., Yong, D. and Hwang, J.K. (2009). In vitro activities of panduratin A against clinical Staphylococcus strains. Antimicrobial Agents and Chemotherapy, 53(10), 4529-4532. https://doi.org/10.1128/AAC.00624-09

Saad, R. (2014). Phytochemical screening and antibacterial activity of five Malaysian medicinal plants. British Journal of Pharmaceutical Research, 4(17), 2019-2032. https://doi.org/10.9734/ BJPR/2014/12233

Smith-Palmer, A., Stewart, J. and Fyfe, L. (1998). Antimicrobial properties of plant essential oils and essences against five important food-borne pathogens. Letters in Applied Microbiology, 26(2), $118-122$. https://doi.org/10.1046/j.1472765X.1998.00303.X

Speck, M.L. and Ray, B. (1977). Effects of freezing and storage on microorganisms in frozen foods: a review. Journal of Food Protection, 40(5), 333-336. https:// doi.org/10.4315/0362-028X-40.5.333

Talaro, K.P. and Chess, B. (2012). Foundations in microbiology, 8th Ed. USA, New York: McGrawHill.

Thangiah, A.S.,Obey, J. and Mutuku, N.C. (2013). Phytochemical analysis of Vernoniaadoensis leaves and roots used as a traditional medicinal plant in Kenya. International Journal of Pharmaceutical and Biological, 3(3), 46-52.

Unklesbay, N. (1992). World Food and You, p. 251. New York, USA: Food Product Press.

Wafa, N., Sofiane, G. and Mouhamed, K. (2016). The antioxidant and antimicrobial activities of flavonoids and tannins extracted from Phlomis bovei De Noé. European Journal of Experimental Biology, 6(3), 5561.

Wei, L.S, Musa, N. and Wee, W. (2010). In vitro antimicrobial activities of Colocasia esculenta extract against Vibrio spp. Journal of Agricultural, 7, 3-7.

Witkowska, A.M., Hickey, D.K., Alonso-Gomez, M. and Wilkinson, M. (2013). Evaluation of antimicrobial activities of commercial herb and spice extracts against selected food-borne-bacteria. Journal of Food Research, 2(4), 37-41. https://doi.org/10.5539/ jfr.v2n 4 p37

Yusoff, N.A.H., Noor, N.F. and Rukayadi, Y. (2015). Effects of Cosmos caudatus Kunth. (ulam raja) extract on microflora in raw chicken meat. International Journal of Current Microbiology and Applied Sciences, 4, 426-435. 